\title{
Physiological adaptation in savanna ungulates
}

\author{
BY A. W. ILLIUS \\ Institute of Cell, Animal and Population Biology, University of Edinburgh, West Mains Road, Edinburgh \\ EH9 $3 J T$
}

Savannas lie between the equatorial rain forests and the semi-deserts of the southern continents. From the herbivore's viewpoint, the savanna environment is characterized by a mixture of herbaceous and woody vegetation, varying in quantity and growth stage according to the seasonal cycle of rainfall. $\mathrm{C}_{4}$ grasses (i.e. those with the $\mathrm{C}_{4}$ photosynthetic pathway) dominate the herbaceous layer, which otherwise comprises dicotyledenous forbs; the woody component consists of fire-tolerant trees and shrubs. The intake of grasses is constrained by their low abundance early in the growing season and by lignification and low digestibility subsequently. The other vegetation components of savanna commonly contain secondary metabolites, such as tannins, in their currently-growing tissue, or are heavily lignified in structural tissue. The phenology of grasses is strongly associated with the incidence of the rainy season, whereas woody browse bears green leaf both before and after the rains. The $\mathrm{N}$ concentration in grasses is generally lower than that in browse, especially in leguminous browse (Fig. 1), and may be lower in the stem and dead tissue of grasses than the effective rumen degradable protein: fermentable metabolizable energy required by rumen microbes (Agricultural and Food Research Council, 1993).

The present paper reviews the problems of the ruminant fauna of the African savannas in extracting energy and nutrients from their food sources. It aims to set the hypothetical physiological adaptations in an ecological context. The contrasts between foregut and hindgut digestive strategies, respectively those of ruminant and non-ruminant ungulates, are discussed elsewhere (Illius \& Gordon, 1992).

\section{ECOLOGICAL CORRELATES OF RUMINANT DIVERSITY}

The striking diversity of savanna ruminants is demonstrated by their wide range of body size, from the royal antelope (Neotragus pygmaeus), weighing $4 \mathrm{~kg}$, to the $700 \mathrm{~kg}$ buffalo, Syncerus caffer. Of the seventy-four species listed by Jarman (1974), one-third weigh less than $20 \mathrm{~kg}$, half weigh less than $50 \mathrm{~kg}$, and one-fifth weigh more than $200 \mathrm{~kg}$. The diets which savanna ruminants select vary in two principal ways: botanically, in the proportions of grasses, forbs and browse, and in quality, which approximates to the inverse of fibre content and its degree of lignification. Observations of diet composition, estimated either from gut contents of shot animals or by direct observation of grazing (Gwynne \& Bell, 1968; Bell, 1970; Hansen et al. 1975; Owaga, 1975; Jarman \& Sinclair, 1979; Murray \& Brown, 1993) lead to the following generalizations. Small-bodied species, such as Thomson's gazelle (Gazella thomsoni), are more selective feeders than larger animals, such as topi (Damaliscus korrigum) and buffalo. All ruminants select against wood, stem and leaf sheath and in favour of leaf lamina, but this tendency is strongest in small species and almost absent in large species. By implication, the digestibility of the diet is higher in the smaller species. Small species have botanically-diverse diets, including a wide range of dicotyledons (forbs) growing in the base of the sward. Large species make less use of short grass than do small species, and are the first to move off swards high on the catena as they become depleted during the dry season. Jarman (1974) provided the first clear exposition of 


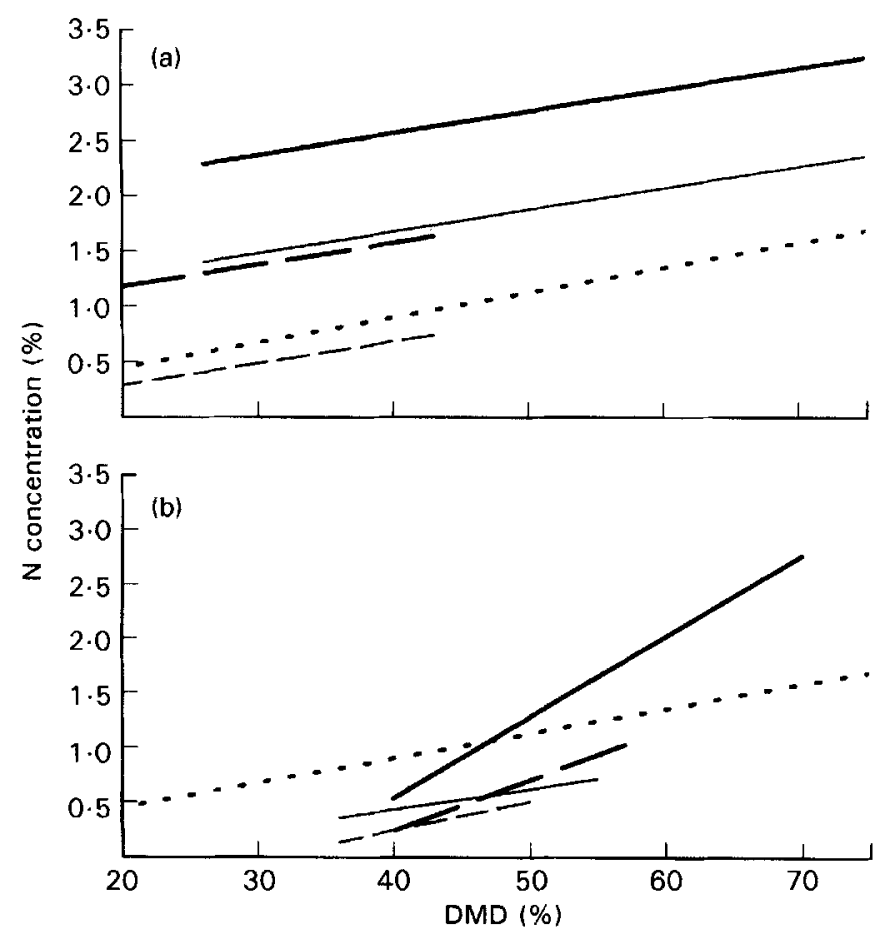

Fig. 1. The relationship between nitrogen concentration (\%) and DM digestibility (DMD; \%) of African vegetation, compared with the estimated effective rumen degradable protein: fermentable metabolizable energy (-----) calculated according to Agricultural and Food Research Council (1993). (a) Browse: leguminous leaf (-) and stem (- - - ) and non-leguminous leaf $(-)$ and stem (- - ). Data from Bamualin (1981) and A. W. Illius (unpublished results; combined regression: $n$ 94; $r^{2} 0.74$; residual SD 0.40 . (b) Grasses: green leaf $(-)$ and stem $(-)$ and dead leaf $(---)$ and stem (- - ). Data from M. G. Murray, unpublished results; combined regression: $n$ 148; $r^{2} 0.75$; residual SD 0.37 .

the association between body size, feeding style, habitat use and diet selection in African antelope, and ventured some physiological explanations. He identified five feeding styles, in terms of the degree of selectivity for plant parts of higher nutritive value, and found that selectivity was negatively related to body size. The most selective feeders, such as duikers, have botanically-diverse diets, avoiding fibrous components of the vegetation where possible. Intermediate selectivity is associated with lower-quality diets and is exhibited by animals in the range from approximately 50 to $200 \mathrm{~kg}$ body weight, which may tend to specialize on either grass or browse, or switch from grass to browse as grass digestibility declines at the end of the wet season. The least-selective feeders, such as buffalo, have botanically-narrow diets, being primarily grazers, and appear to tolerate the seasonal patterns of digestibility brought about by the phenology of grass maturation, stem formation and senescence.

Bell (1970) and Jarman (1974) argued that, since gut capacity scales isometrically with body mass $\left(\mathbf{M}^{1}\right)$, but metabolic requirements scale with the $\mathbf{M}^{0.75}$, then the rate of the animals' metabolism per unit digesta load would scale as $M^{-0.25}$ (i.e. scales negatively with M). This implies that large animals can afford to select diets of lower diet digestibility than can small animals, but does not explain why they should choose to do so. The relationship between dietary selectivity and body size can be explained first by the inability of large animals, with their large mouthparts, to discriminate between plant parts whilst 
feeding (Gordon \& Illius, 1988). Comparison of the incisor arcade morphology of eightynine species of ruminant shows that, by comparison with smaller and more-selective animals, large-bodied grazers have broader and flatter incisor arcades which are adapted to maximizing bite mass at the expense of selectivity. Conversely, large-bodied browsers have narrower and more-pointed incisor arcades, which would be expected to enhance the avoidance of woody plants parts during selection of leaf. A further constraint on diet choice is thought to arise from the allometries of incisor arcade breadth and metabolic requirements with animal mass. From a mathematical model of the interaction between dentition and sward structure, Illius \& Gordon (1987) predicted that the allometric exponent relating bite mass to $M$ would decline from 0.72 to 0.36 as sward surface height was progressively reduced. Comparing bite mass with metabolic requirements of animals, large animals would thus be predicted to be at a disadvantage to smaller ones when grazing short swards, because each bite represents a smaller proportion of daily requirements. Diminished tolerance in large grazers of short swards would explain why they are observed to be the first to switch from short, digestible swards to swards with greater biomass but lower digestibility.

In conclusion, the morphology and allometry of the mouthparts impose constraints on selectivity which are more severe in larger animals, limiting the quality of diet they can select from heterogeneous vegetation or low-biomass vegetation. This poses two questions: is the prediction that larger animals eat lower-digestibility diets supported by observation; and, what adaptations to lower diet quality have evolved in relation to body size and the botanical composition of the diet? These are addressed below.

\section{BODY SIZE AND DIET DIGESTIBILITY}

Rumen fermentation rate has been extensively studied in African ruminants, and is found to scale negatively with M (Hoppe, 1977; Gordon \& Illius, 1994). In a comparison of ten grazing species (M 18-807 kg) and eleven species of browser (M 3.7-703 kg), rumen fermentation rate was found to be $12.4 \mathrm{M}^{-0.23}$ mol volatile fatty acids (VFA)/ $\mathrm{kg}$ DM per d $\left(r^{2} 0.69\right)$, with no significant difference between the grazers and browsers $\left(\mathrm{F}_{1,18} 1.25\right.$; Gordon \& Illius, 1994). The higher fermentation rate in smaller animals is strongly suggestive of their selecting higher-quality diets.

In one of the few direct attempts to compare diet quality across a range of African ungulates, Owen-Smith (1988) collated published data on the non-stem component of dryseason diets. This was assessed by rumen sampling, which may involve some bias in the ratio, rapidly-: slowly-fermenting components. Considering only the ruminants, the nonstem proportion of the diet was negatively related to body size, being $1.32 \mathrm{M}^{-0.15}$ in grazers ( $n 9 ; \mathrm{M} 19-480 \mathrm{~kg}$ ), and $0.98 \mathrm{M}^{-0.047}$ in browsers $\left(n 9 ; \mathrm{M} 4-970 \mathrm{~kg} ; r^{2} 0.69\right.$ ). Large browsers evidently avoid the non-stem components more than do large grazers. Taking the mean digestibility of leaf and stem to be respectively 0.56 and 0.43 in $\mathrm{C}_{4}$ grasses and 0.50 and 0.29 in browse (for sources of data, see Fig. 1), diet digestibility can be estimated to be $0.56 \mathrm{M}^{-0.019}$ in grazers, and $0.50 \mathrm{M}^{-0.019}$ in browsers $\left(r^{2} 0.78\right)$. Three conclusions can be drawn from this analysis. First, grazers and browsers appear to share the same relationship between body size and diet digestibility. Second, browse diets appear to be about $12 \%$ less digestible than grass diets, although the difference in energy intake would be greater if account is taken of the diluting effect of soluble secondary plant compounds (Robbins et al. 1995; Gordon \& Illius, 1996). Third, the average diet digestibility in animals of 5 and $500 \mathrm{~kg}$ respectively can be predicted to be 0.51 and 0.47 , which is a much smaller decline than field observations of foraging behaviour and the comparative fermentation data had suggested. 
The discrepancy between diet-quality scaling estimated from fermentation and digesta composition data can be reconciled as follows. Gordon \& Illius (1996) estimated the potential digestibility (the sum of cell contents and potentially-digestible cell wall) of diets required to support the observed fermentation rates, using a simulation model of rumen kinetics (Illius \& Gordon, 1991, 1992) which integrates effects of animal size and plant characteristics. Converting this to estimated in vitro DM digestibility (DMD) shows a slight decline with body size, being $0.86 \mathrm{M}^{-0.049}$ for both browsers and grazers, or 0.79 and 0.63 in animals of 5 and $500 \mathrm{~kg}$ respectively. One of the reasons for this decline being less than the decline in fermentation rate with mass is the effect of mass on digesta composition. The retention time of dietary fractions varies with their fermentation rate, and this acts to concentrate the more refractory components. Illius \& Gordon (1991) showed that both the time taken to comminute large fibre particles and the small particulate retention time scale with $\mathbf{M}^{\mathbf{0 . 2 7}}$, and the result is that large animals will have a greater rumen concentration of slowly-digesting fibre components. Since fermentation rates are expressed as the rate of VFA production per unit digesta, large animals would have lower quoted fermentation rates even on the same diet (estimated to scale with an allometric exponent of -0.066 by Gordon \& Illius (1996)). In conclusion, the implication of the fermentation data that diet quality varies widely with body size is probably unwarranted. It appears that the diets selected by African ruminants, in fact, do not vary much in quality when compared in the same season. In support of this, the data of Zeeman et al. (1983) suggest that seasonal differences in diet digestibility outweigh differences between animals of different body sizes. Moreover, the observed range in diet quality appears to be less than the predicted diet quality required to avoid weight loss, which is $0.87 \mathrm{M}^{-0.081}$, i.e. digestibilities of 0.76 and 0.52 respectively in animals of 5 and $500 \mathrm{~kg}$.

An assessment of the impact of low nutritional quality must consider not only the immediate effect of an energy deficit but also its longer-term effect on the depletion of body reserves and, hence, on survival. Large animals are expected to have greater fasting endurance, as was first proposed by Lindstedt \& Boyce (1985). The fat reserves of African ruminants were determined from the data of Ledger (1968) on dissected fat contents of fourteen species of African ungulates, corrected to chemical fat content using a relationship derived from data of $\mathrm{B}$. Mitchell (unpublished results; chemical fat $(\%)=2.9+3.525$ (SE $1.15)$ dissected fat (\%);n 123; $\left.r^{2} 0.85\right)$. This gave the mass of fat, averaged across sexes, as: $0.064 \mathrm{M}^{1.154}$ (SE 0.064$) \mathrm{kg}$, which is consistent with previous estimates for mammals (Lindstedt \& Boyce, 1985; Millar \& Hickling, 1990). In addition to body fat, animals mobilize tissue protein during weight loss, and it may be assumed that loss of about onethird of tissue protein is feasible before death is likely (Reimers et al. 1982; Torbit et al. 1985). If it is further assumed that these reserves must make good a dietary energy deficit for a 6-month dry season, when food quality is poor, it is possible to estimate the minimum rate of dietary energy supply which is consistent with survival and, thus, the minimum feasible diet quality on which the animal can subsist. Accordingly, the endurance metabolism of an animal, defined as the minimum exogenous energy requirement during maximum tissue mobilization, is $0.45 \mathrm{M}^{0.565} \mathrm{MJ} / \mathrm{d}$, compared with the standard requirement for weight stasis of $0.35 \mathrm{M}^{0.73} \mathrm{MJ} / \mathrm{d}$ (Brody, 1945). Thus, weight loss would provide about 0.54 of the daily energy requirements of an animal weighing $500 \mathrm{~kg}$, but less than 0.02 of those of an animal of $5 \mathrm{~kg}$. The minimum food quality which would supply this requirement for energy if eaten at the maximum rate allowed by the animal's digestive capacity was determined using the model of ruminant digestion kinetics of Illius \& Gordon (1991). The minimum DMD of the diet is thus $0.88 \mathrm{M}^{-0.143}$, being 0.70 and 0.36 in animals of 5 and $500 \mathrm{~kg}$ respectively. There are two clear results from this analysis. First, 
large ungulates have greater dietary tolerance than small ones, allowing them to exploit a wider range of diet quality. Second, large animals have the advantage of greater reserves of mobilizable tissues relative to their rate of daily energy expenditure.

It is evident from the previous discussion that dietary quality observed in African ruminants declines with body size, due to constraints on selective ability and the scarcity of high-quality food. The decline is apparently less severe than that which would cause large animals to lose weight at a faster rate than small animals, and it is markedly less than large animals can tolerate when their body reserves are considered. Although large animals may have only slightly-less-digestible diets than smaller animals, the multiplicative effects on energy intake may be substantial (White, 1983). Illius \& Gordon (1991) suggested that, when compared on the same foods, the longer retention time of large animals resulted in greater digestion (digestibility approximately $\mathrm{M}^{0.07}$ ), allowing greater DM intake (approximately $\mathrm{M}^{0.81}$ ), and these have multiplicative effects on metabolizable energy intake (approximately $\mathbf{M}^{0.89}$ ). The ability of large animals to obtain, on the same food, a greater proportion of their metabolic requirements than small animals would be expected to exert strong selection pressure for the evolution of large body size (Illius \& Gordon, 1992). This suggests that size itself is an important adaptation of savanna ungulates, because the effect of lower selectivity in large animals would appear to be easily outweighed by their greater digestive efficiency and fasting endurance.

\section{DIGESTIVE TRACT MORPHOLOGY AND DIET}

In the classical description by Hoffman (1973, 1989), morphological diversity in the digestive tracts of ruminants is portrayed as an adaptation to botanical diversity of the diet. Browse diets generally differ from grass diets in the ratio of their fermentable substrates, with browse containing a higher proportion of cell contents, but greater lignification of the cell wall. The implication is that the optimal digestive strategy of browsers would be to specialize on utilization of the rapidly-fermentable cell contents and not to retain the poorly-digestible cell wall. Conversely, grazers should retain the fermentable cell-wall component of their diets for long enough to allow extensive digestion. Thus, at the two extremes of botanical dietary specialization, ruminants which browse are classed as 'concentrate selectors' while grazers are regarded as 'bulk or roughage feeders'. A third category, 'intermediate feeders' take a mixture of browse and grass, often switching seasonally. Representatives of each category can be found across the range of body size. Hoffman $(1973,1989)$ identified a number of anatomical features which, hypothetically, are adaptations to these diverse strategies. In consequence, he argued that concentrate selectors have lower rumen volume than bulk roughage feeders but greater dependence on hindgut fermentation, higher passage rate, higher rumen VFA concentrations and fermentation rate, higher parotid salivary gland mass to increase buffering and liquid passage, and lower efficiency of cell-wall digestion.

The inference that these three dietary categories show adaptive variation in digestive physiology is drawn largely from comparative anatomical evidence, but has been thrown into question by comparative data on digestion kinetics. Gordon \& Illius (1994) assembled published data from eleven species of African browsing ruminant and ten species of grazers. Allometric analysis demonstrated that the wet and dry digesta load of the rumen and hindgut, rumen fermentation rate, and particulate passage rate did not differ significantly between dietary classifications, but were strongly related to $M$. The daily energy supply from rumen VFA in browsers was 0.75 of that in grazers, but VFA energy supply from the hindgut did not differ. Robbins et al. (1995) produced further evidence that 
morphological differences between feeding type do not necessarily correspond to differences in function. They found that rumen fractional outflow rate was unrelated to feeding type or body size. Although parotid gland mass was markedly higher, after controlling for body size, in most browsers than that in grazers, there were a number of exceptions. Robbins et al. (1995) argue that the secretion of tannin-binding salivary proteins is a likely functional explanation for larger parotid gland mass in animals which browse. The data presented by Prins et al. (1984) demonstrate that the cellulolytic activity of the rumen microflora of concentrate selectors is approximately $40 \%$ of the activity in bulk roughage feeders. This suggests adaptation of the amylolytic:cellulolytic ratio of rumen microflora to the lower concentration of digestible cell wall in grass diets. However, in vivo comparisons by Robbins et al. (1995) demonstrated that the extent of fibre digestion did not differ between feeding types, although it was greater in larger animals. This conclusion has been questioned by van Wieren (1996) and Iason \& van Wieren (1997), based on analysis of a more extensive dataset.

The very notion that immature browse provides a 'concentrate' diet was questioned by Robbins et al. (1995). The diluting effect of soluble secondary plant compounds of typical browses has in the past led to their nutritive value being overestimated. Browse contains little starch and, therefore, would not be expected to give rise to the low acetate : propionate values found on starch-based diets (Hoppe, 1984; Gordon \& Illius, 1994). The presumption that acetate:propionate values would differ between browsing, intermediate and grazing African ruminants according to substrate was not supported by evidence from Clemens $e t$ al. (1983), who suggested that $M$ had more influence than feeding habits on rumen fermentation rate and VFA ratios. Robbins et al. (1995) argued that, if browse does not generally provide a 'concentrate' diet, then physiological and ecological interpretations based on that premise are unfounded.

On the basis of most, if not all, of the factors so far examined, morphological distinctions between dietary categories of ruminant appear not to be related to function in the ways hypothesized by Hofmann (1989). The classification is, therefore, of doubtful validity, beyond the recognition that animals differ in the diets they select. The actual adaptive significance of their morphological diversity remains obscure. The weaknesses of comparative analyses of digestion and passage kinetics are that data are scarce and have to be combined from many sources with differing experimental techniques, although statistical procedures may partly overcome the latter deficiency. Such analyses do, on the other hand, represent the first rigorous test of Hofmann's (1989) hypotheses. Until further critical comparisons of a large number of species are undertaken, it appears that to ascribe functional significance to anatomical differences has been premature. Instead, we may conclude that digestion and passage kinetics are more under the control of plant than of animal attributes, and that body size and its physiological correlates appear to be adaptive features of over-riding importance in ruminant nutritional ecology.

I am grateful to M. G. Murray for allowing me access to unpublished data. I acknowledge the fruitful collaboration with I. J. Gordon in much of the work reported here.

\section{REFERENCES}

Agricultural and Food Research Council (1993). Energy and Protein Requirements of Ruminants. An Advisory Manual Prepared by the AFRC Technical Committee on Responses to Nutrients. Wallingford: CAB INTERNATIONAL.

Bamualin, A. (1981). Nutritive value of some tropical browse species in the wet and dry seasons. MSc Thesis, James Cook University of North Queensland, Australia. 
Bell, R. H. V. (1970). The use of the herb layer by grazing ungulates in the Serengeti. In Animal Populations in Relation to their Food Supply, pp. 111-123 [A. Watson, editor]. Oxford: Blackwell Scientific.

Brody, S. (1945). Bioenergetics and Growth. New York: Reinhold.

Clemens, E. T., Maloiy, G. M. O. \& Sutton, J. D. (1983). Molar proportions of volatile fatty acids in the gastrointestinal tract of East African ruminants. Comparative Biochemistry and Physiology 76A, 319-333.

Gordon, I. J. \& Illius, A. W. (1988). Incisor arcade structure and diet selection in ruminants. Functional Ecology 2, 15-22.

Gordon, I. J. \& Illius, A. W. (1994). The functional significance of the browser-grazer dichotomy in African ruminants. Oecologia $98,167-175$.

Gordon, I. J. \& Illius, A. W. (1996). The nutritional ecology of ruminants: a reinterpretation. Journal of Animal Ecology 64, 18-28.

Gwynne, M. D. \& Bell, R. H. V. (1968). Selection of vegetation components by grazing ungulates in the Serengeti National Park. Nature 220, 390-393.

Hansen, R. M., Mugambi, M. M. \& Bauni, S. M. (1975). Diets and trophic ranking of ungulates of the northem Serengeti. Journal of Wildlife Management 49, 823-829.

Hofmann, R. R. (1973). The ruminant stomach: stomach structure and feeding habits of East African game ruminants. East African Monographs in Biology no. 2. Nairobi, Kenya: East African Literature Bureau.

Hofmann, R. R. (1989). Evolutionary steps of ecophysiological adaptation and diversification of ruminants. A comparative view of their digestive system. Oecologia 78, 443-457.

Hoppe, P. P. (1977). Rumen fermentation rate and bodyweight in African ruminants. Proceedings of the XIIIth International Congress of Game Biologists, pp. 141-150. Washington, DC: The Wildlife Society.

Hoppe, P. P. (1984). Strategies of digestion in African herbivores. In Herbivore Nutrition in the Subtropics and Tropics, pp. 222-243 [F. M. C. Gilchrist and R. I. Mackie, editors]. Craighall, South Africa: The Science Press.

Iason, G. R. \& van Wieren, S. E. (1997). Adaptations of mammalian herbivores to low quality forage. In Herbivores, Plants and Predators [H. Olff, V. K. Brown and R. H. Drent, editors]. Oxford: Blackwell Scientific (In the Press).

Illius, A. W. \& Gordon, I. J. (1987). The allometry of food intake in grazing ruminants. Journal of Animal Ecology 56, 989-999.

Illius, A. W. \& Gordon, I. J. (1991). Prediction of intake and digestion in ruminants by a model of rumen kinetics integrating animal size and plant characteristics. Journal of Agricultural Science, Cambridge 116 , 145-157.

Illius, A. W. \& Gordon, I. J. (1992). Modelling the nutritional ecology of ungulate herbivores: evolution of body size and competitive interactions. Oecologia 89, 428-434.

Jarman, P. J. (1974). The social organization of antelope in relation to their ecology. Behaviour 48, $215-266$.

Jarman, P. J. \& Sinclair, A. R. E. (1979). Feeding strategies and the pattern of resource partitioning in ungulates. In Serengeti: Dynamics of an Ecosystem, pp. 130-163 [A. R. E. Sinclair and M. Norton-Griffiths, editors]. Chicago: University of Chicago Press.

Ledger, H. P. (1968). Body composition as a basis for a comparative study of some East African mammals. Symposium of the Zoological Society of London 21, 289-310.

Lindstedt, S. L. \& Boyce, M. S. (1985). Seasonality, fasting endurance and body size in mammals. American Naturalist 125, 873-878.

Millar, J. S. \& Hickling, G. J. (1990). Fasting endurance and the evolution of mammalian body size. Functional Ecology 4, 5-12.

Murray, M. G. \& Brown, D. (1993). Niche separation of grazing ungulates in the Serengeti: an experimental test. Journal of Animal Ecology 62, 380-389.

Owaga, M. L. (1975). The feeding ecology of wildebeest and zebra in Athi-Kaputei plains. East African Wildlife Journal 13, 375-383.

Owen-Smith, R. N. (1988). Megaherbivores. Cambridge: Cambridge University Press.

Prins, R. A., Lankhorst, A. \& van Hoven, W. (1984). Gastrointestinal fermentation in herbivores and the extent of plant cell-wall digestion. In Herbivore Nutrition in the Subtropics and Tropics, pp. $403-434$ [F. M. C. Gilchrist and R. I. Mackie, editors]. Craighall, South Africa: The Science Press.

Reimers, E., Ringberg, T. \& Sørumgård, R. (1982). Body composition of Svalbard reindeer. Canadian Journal of Zoology 60, 1812-1821.

Robbins, C. T., Spalinger, D. E. \& van Hoven, W. (1995). Adaptations of ruminants to browse and grass diets: are anatomical-based browser-grazer interpretations valid? Oecologia 103, 208-213.

Torbit, S. C., Carpenter, L. H., Swift, D. M. \& Alldredge, A. W. (1985). Differential loss of fat and protein by mule deer during winter. Journal of Wildlife Management 49, 80-85.

van Wieren, S. E. (1996). Digestive strategies in ruminants and nonruminants. PhD Thesis, Landbouw Universiteit, Wageningen, The Netherlands.

White, R. G. (1983). Foraging patterns and their multiplier effect on productivity of northern ungulates. Oikos 40, 377-384. 
Zeeman, P. J. L., Marais, P. G. \& Coetsee, M. J. (1983). Nutrient selection by cattle, goats and sheep on natural Karoo pasture. 1. Digestibility of organic matter. South African Journal of Animal Science 2, 236-239. 